\title{
Sustainable Business Models for Public Sector Open Data Providers
}

\section{Frederika Welle Donker and Bastiaan van Loenen}

Delft University of Technology, Faculty of Architecture and the Built Environment, Delft, The Netherlands

Abstract: Since 2009, Open Government Data initiatives have been launched worldwide and the concept of open data is gaining momentum. Open data are often associated with realizing ambitions, such as a more transparent and efficient government, solving societal problems and increased economic value. However, between proposing an open data policy and successful implementation are some practicable obstacles, especially for government agencies required to generate sufficient revenue to cover their operating costs, so-called self-funding agencies. With lost revenue due to open data, there is a real risk that the update frequency and the quality of data may suffer or that the open data policy may even have to be reversed. This article has researched the financial effects of open data policies for self-funding agencies on their business model. The article provides several hands-on proposals for self-funding agencies having to implement an open data policy whilst ensuring their long-term sustainability.

Keywords: open data; implementation of open data policy; business models; sustainability; self-funding agencies

Acknowledgement: We would like to thank Martine van Heijnsbergen and Hans Lambeck of RDW; Dick Eertink of Kadaster; Rob van der Krogt and Tirza van Daalen of TNO; Freddy Keij of Kamer van Koophandel; Cassy Short, Kate Chaloner, Merry Branson, Stuart Kevin and Tim Montgomery of the Australian Bureau of Statistics; and Jo Jones and Stephen Lewis of Companies House, UK for their kind cooperation.

\section{Introduction}

\subsection{Open Data of Self-Funding Agencies}

Open government data are often associated with realizing ambitions such as a more transparent and efficient government (e.g., Huijboom and van den Broek 2011), improved citizens' participation (Jetzek 2013), solving societal problems (e.g., Uhlir 2009) and increasing economic value by companies creating innovative products and services using open data as a resource (e.g., 
Omidyar Network 2014). Governments worldwide are adopting open data policies for their data, for instance, the G8 Open Data Charter of 2013'. However, between proposing an open data policy and successful implementation are some practicable obstacles, especially for government agencies required to generate sufficient revenue to cover a substantial part of their operating costs - socalled self-funding agencies, e.g., the UK Trading Funds ${ }^{2}$. Large-scale geographical data are expensive to collect and maintain. In many countries, self-funding agencies are often monopolist providers of such high-value data and rely on income generated by licence fees for supplying data as part of their business model (Onsrud 1992).

Self-funding agencies are increasingly under political and societal pressure to release their highvalue data as open data. However, without a sustainable open data business model for selffunding agencies there is a real risk that the update frequency and the quality of data may suffer or that the open data policy may have to be reversed (van Loenen 2009). To offset revenue losses due to open data, self-funding agencies either have to be compensated by the central government or have to increase revenues raised by other activities, which may give rise to competition concerns (DotEcon 2015). Another concern is that self-funding agencies may only publish open datasets with the least commercial value, while retaining the more valuable data to minimise the risk to commercial revenues (Rhind 2014). There may also be a fear that "open data could be immediately 'swallowed up [...] by big global companies' and not benefit the national economy" (Michael Fallon, UK Minister for Business and Enterprise, cited by PASC 2014).

Much of the past research focussed on the potential benefits of open data without taking into account the financial effects on the data providers, even though financial aspects are a core part of an organisation's business model. In resolving the tension between the problem of lost revenue due to open data and the need to maintain adequate data service quality, a solution could be to develop a sustainable business model for open government data providers that ensures the availability of quality open data in the long term.

This article has researched different business models that may be suitable for self-funding government agencies considering adopting open data policies. We have researched alternative and innovative business models to find out if these business models can be adopted or adapted. Our research questions are: Which business models are currently employed by government open data providers and How can such a business model be made sustainable to ensure the availability of high quality open data in the long term? As part of our research, we have studied the effects of open data on the business

${ }^{1}$ https://www.gov.uk/government/uploads/system/uploads/attachment_data/file/207772/Open_Data_ Charter.pdf

${ }^{2}$ Trading funds are defined by the UK Treasury as "public corporations [whose] activities are not consolidated with their sponsor departments' business. They must finance their operations from trading activity."

(https://www.gov.uk/government/uploads/system/uploads/attachment_data/file/454191/Managing _Public_Money_AA_v2_-jan15.pdf, p.56) 
model of three Dutch government agencies, the Kadaster, the National Transport Agency (RDW) and the Dutch Chamber of Commerce, and one research institute TNO. These cases were selected because the first three organisations are self-funding agencies allowed by law to charge fees for data, and the fourth case concerns a non-governmental organisation with a public mandate. All four organisations are key register data administrators and although these organisations rely on generating income from fee-based services to cover a substantial part of their operating costs, they are under pressure to supply key register data as open data. In addition, we have researched two international government agencies that can be considered 'best practice' open data providers, the Australian Bureau of Statistics and the United Kingdom Companies House. The Australian Bureau of Statistics was selected because it was one of the first organisations to switch to open data in 2005. Thus, this case demonstrates the longer-term effects of open data. The Companies House was selected because their public tasks and datasets are comparable to the Dutch Chamber of Commerce and have recently switched to providing open data. These case studies may offer inspiration for other government agencies having to make the switch from fee-based data and services to open data.

\subsection{Dutch Legal Framework}

The legal framework for accessibility of government data in the Netherlands follows the European Union's framework laid down in the so-called Amended Public Sector Information (PSI) Reuse Directive $(2013 / 37 / \mathrm{EU})^{3}$ the so-called INSPIRE Directive (2007/2/EC) ${ }^{4}$ establishing an Infrastructure for Spatial Information in the European Community, and the system of key registers.

\subsubsection{Public Sector Information Re-Use Act}

The transposed Amended PSI Reuse Directive came into force on 18 July 2015 and modified the regime of the Public Information Access Act. The aim of the PSI Reuse Act is to make all suitable public government data available for reuse with as few legal restrictions as possible, through open and machine-readable formats together with their metadata. In principle, charges should not exceed marginal dissemination costs. The PSI Reuse Act lists only three self-funding public sector bodies (Kadaster, National Transport Agency (RDW) and Chamber of Commerce) that are allowed to charge higher fees, provided these fees do not exceed the total costs of production and dissemination. The PSI Reuse Act confirms the general open government data policy already in place in the Netherlands since the adoption of the EU Digital Agenda in 2011: All government data should be "open, unless", i.e.,that government data should be available as open data unless there

${ }^{3}$ Directive 2013/37/EU of the European Parliament and of the Council of 26 June 2013 amending Directive 2003/98/EC on the re-use of public sector information. 26 June 2013.

4 Directive 2007/2/EC of the European Parliament and of the Council of 14 March 2007 establishing an Infrastructure for Spatial Information in the European Community (INSPIRE). 
are limitations such as privacy-sensitive data, commercially-sensitive data and data related to state security.

\subsubsection{Geographical Information Infrastructure Implementation $\mathrm{Act}^{5}$}

The transposed INSPIRE Directive came into force on 1 September 2009. The INSPIRE Implementation Act provides a framework of general rules, implementing rules and measures aimed at the establishment of a geographical information infrastructure to facilitate policy-making and measures that may have an impact on the environment. The framework addresses accessibility and exchange of geographical data across various levels of public authority and across different sectors through harmonisation and standardisation. The INSPIRE Implementation Act requires that INSPIRE datasets ${ }^{6}$ are described through metadata, have interoperable formats and are accessible through network services with minimum performance criteria for those services. These criteria relate to performance, capacity and availability of network services. INSPIRE requires that public access to discovery and viewing services are without costs but download services may be subject to licences and charges. To meet the INSPIRE requirements; the Dutch government has developed PDOK', a portal with web services for discovering, viewing and downloading government geographical data. Many PDOK web services are based on open data and thus, available to everyone.

\subsubsection{Key Register System}

To improve the information infrastructure in the Netherlands, the government has developed a system of key registers of core reference data. The ultimate goal of this system is to collect core reference data once and reuse it many times. To achieve this, key registers are regulated by law: One government organisation is responsible as the administrator of key register data and provider of a key register, other government bodies are obliged to reuse key register data to prevent multiple collection of similar data, and government users are obliged to report any errors to the data manager. Together, key registers form part of a System of Key Registers, whereby authentic data from one register is reused in another register, e.g., the addresses of the Key Register Addresses are reused in the Key Register Cadastre. Of the 12 allocated key registers, six have a geographical component and six are administrative registers. The ultimate aim is that key registers

${ }^{5}$ This section builds on van Loenen and Grothe (2014).

${ }^{6}$ INSPIRE applies to 34 content themes, ranging from specific geographic reference data themes (e.g., transport networks, cadastral parcels, buildings, ortho-imagery, elevation, statistical and administrative units) to environmental themes (e.g., geology, habitats and biotopes, human health and safety, meteorology, hydrology, oceanographic features)

7 PDOK ("Maps for Public Services") was established by the Ministry of Infrastructure \& the Environment, the Ministry of Economic Affairs, the Department of Public Works and the Kadaster, and is primarily employed for reuse of geographical data between public sector bodies. 
will be available for reuse within the government without financial barriers. Key registers that are not under financial constraints and do not contain personal data are made available as open data.

Although the Key Register System predates INSPIRE, together they form a framework for a national information infrastructure.

\subsection{Reading Guide}

In the next chapter, we describe business model theory and business model components. After an overview of the spectrum of current data policies, we elaborate further on two components of business models, the service component and the financial component and specifically potential revenue models. Section 3 introduces information value chains and describes the different activities that are part of an information value chain. We explain which roles a public sector data provider may adopt in this information value chain and illustrate the relationship between business model components and roles within information value chains. Section 4 describes and analyses the six case studies. In addition, we address financial implications of open data for selffunding agencies. In Section 5, we use our analyses to provide conclusions and recommendations.

\section{Business Models}

A literature review has shown that there are many definitions for the concept of business models. For instance, Ovans (2015) proposes that a business model is more about strategies and assumptions than about money. Osterwalder and Pigneur (2010, p.14) state that "A business model describes the rationale of how an organization creates, delivers, and captures value". Rappa (2010) adds to this definition the goal of a company: Namely, to generate revenue. For this article, we adhere to the definition that a business model describes the strategies an organisation can employ to reach a certain goal. For a company producing physical goods the goal may be simple: Sell products in order to generate a profit. For government agencies whose goal it is to provide a specific public service, the business model becomes more complex as there may be specific legal constrains and obligations.

\subsection{Components of a Business Model}

De Reuver et al. (2008) distinguish four common components of a business model: a service component, a technical component, an organisational component and a financial component (cf. Johnson, Christensen and Kagermann 2008, Osterwalder and Pigneur 2010). These components are not isolated but are mutually interconnected.

- The service component describes the type of service on offer, the target audience and market segment (government, businesses, consumers), and the added value of the service to the enduser. The service component determines the design of the other components.

- The technical component describes the architecture, infrastructure, data security, and other technical aspects needed to develop a service, and the way in which this service is delivered to the end-user. 
- The organisational component describes the value network required to realise a certain service. A value network consists of actors with certain resources and capabilities, which interact and together perform value activities, to create value for customers and to realize their own strategies and goals (Bouwman, Haaker and de Vos 2008, p.56). Legislation and policies provide the framework within which an organisation can operate.

- The financial component describes the financial resources required to develop and deliver a service (cost model) and in which way revenue is generated (revenue model). In the financial component attention must be paid to incoming revenue on one side and all production costs, transaction costs, investments and risk mitigation on the other side. It should be noted that the costs for online services are characterised by a high ratio of fixed to variable costs (Shapiro and Varian 1999).

We focus on the service component as it forms the starting point of any business model, and on the financial component as this component determines the sustainability of all other components, i.e., the finances determine the level of service, the technical and organisational aspects.

\subsection{Service Component}

The service model describes the type of service on offer (what), the intended target group and/or market segment (to whom) and the added value to the user (why). The service component has a direct relation with the position or role of an organisation in the (information) value chain (in which capacity). For government open data organisations, the services on offer would typically be web services for viewing and/or downloading open data, possibly in combination with fee-based services. The target audience for open data is society at large, i.e., other government bodies, companies and citizens. As each user has its own preference for file formats, attributes, et cetera, it will be, therefore, impossible to set up services tailor-made to all types of users. However, a public sector organisation can elect to set up services for a specific market segment, such as other public sector bodies, and to outsource data supply to other segments, such as the private sector and citizens.

\subsection{Financial Models and Data Policies}

In the previous section, we have described which activities (what) an organisation can undertake and which role the organisation can adopt (in which capacity). In this section, we will describe the financial component of a business model. The financial component breaks down into two models, the cost model (what will it cost) and the revenue model (how will costs be recovered). After we describe the spectrum of data policies, we will explore existing revenue models.

Roughly speaking, there are two data policies for government agencies providing data to users: a cost recovery policy and an open data policy. With a cost recovery model, all costs incurred in production, maintenance and dissemination of data are recovered from the users of the data by charging licence fees (see e.g., de Vries et al. 2011, Fornefeld et al. 2008, Longhorn and Blakemore 2008, van Loenen 2006, Onsrud 2004). Data are made available under a licence agreement, usually with restrictive licence conditions. The pricing models used to set the licence fees, may be (one-off) 
fees per area or per kBs, subscription fees, fixed access fees, royalties or a combination of these models (Welle Donker 2009). The revenue raised by licence fees flows directly back to the data provider. Thus, the data provider has certainty of covering its (partial) operational costs. Figure 1 shows the data flows and financial flows of the cost recovery policy.

Figure 1: Cost recovery policy for data (P. Boers (personal communication April 17, 2015) after van Loenen 2006, p.106)

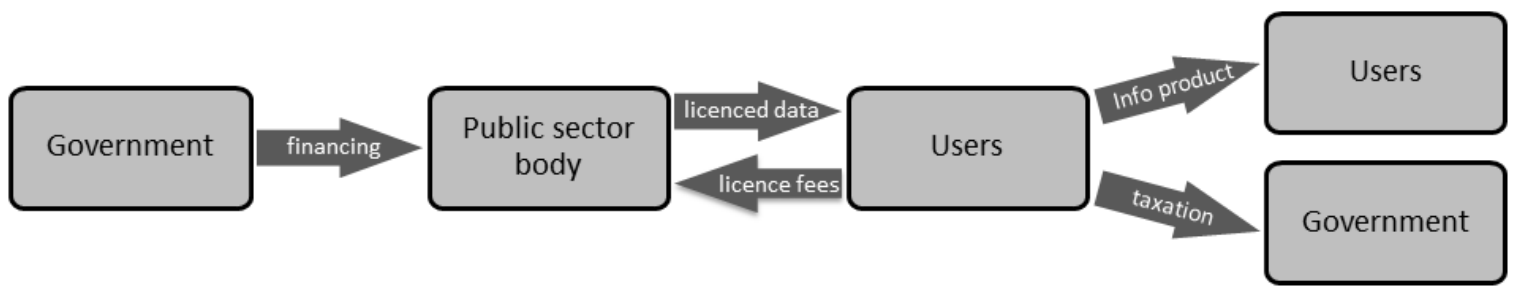

On the other end of the spectrum is an open data policy. Data are provided free of charge and without licence restrictions. There is no direct revenue for the data provider; instead, the data provider depends on the Treasury to finance its operational costs. There is an expectation that when open data are used for value-added products and services, revenue in the form of company taxes and value-added taxes will flow back to the Treasury (e.g., Vickery 2011, Pira et al. 2000, Koski 2011, de Vries et al. 2011). However, the data provider will largely depend on political decisions to maintain adequate funding levels (Onsrud 1992). If funding for a data provider is reduced, the update frequency and quality of the datasets may have to be reduced. In addition, there are no guarantees that revenue raised from taxation will be returned to the appropriate public sector body (Longhorn and Blakemore 2008). Figure 2 shows the data flows and financial flows of the open data policy.

Figure 2: Open data policy (P. Boers (personal communication April 17, 2015) after van Loenen 2006, p.106)

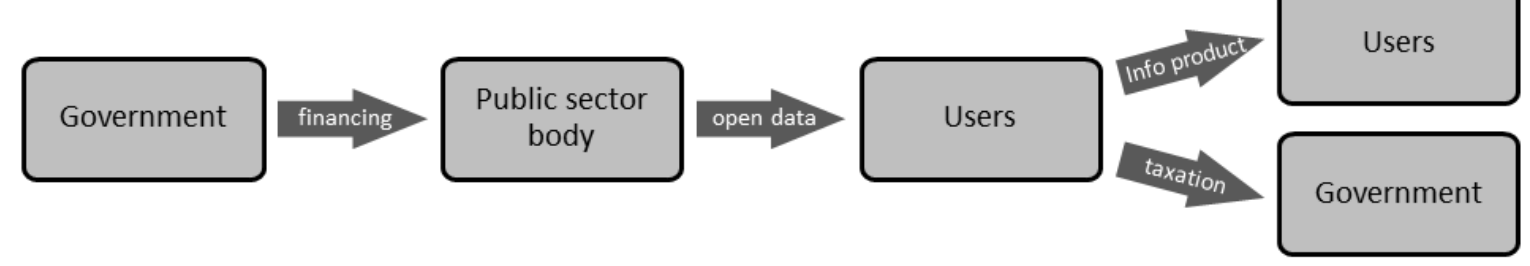

There are many data policies between these two ends of the spectrum. In the following section, we will explain these in more detail. 


\subsection{Revenue Models for Public Sector Organisations}

From a literature review, we identified eight possible revenue models for public sector bodies. Of these eight, the first five are single revenue models, the latter three are combinations of revenue models.

\subsubsection{Open Data Model: Budget Financing}

Open data are supplied free of charge. The costs are financed out of general revenue / annual budget of the organisation. There are no direct benefits to the data provider. However, the indirect benefits may be efficiency gains (Houghton 2011), improved decision-making (Janssen, Charalabidis and Zuiderwijk 2012), strengthen law enforcement (Huijboom and van den Broek 2011), a better informed citizen, lower levels of citizen's perception of corruption (Granickas 2013), or more innovative applications based on the open data and thereby higher societal benefits (e.g., Newbery, Bently and Pollock 2008, Huijboom and van den Broek 2011).

\subsubsection{Legal Instruments}

Governments have legal instruments available to generate revenue. Next to general taxation, e.g., income taxes, (local) governments may levy taxes for a specific purpose, e.g., road taxes, council rates, compulsory company registration charges and/or adjust existing tariffs to balance the budget. Another legal instrument is to make authenticated data products mandatory for certain transactions, e.g., a certified copy of a cadastral registration is compulsory when buying and selling a property, and only the Land Registry Office can issue such certified copies.

\subsubsection{Subscription Model}

A product can be used after an upfront fee has been paid for a specific period. Subscription models are best suited to services that are used frequently (Rappa 2010). There may be subscription differentiation between different types of users. The advantage of this model is that the data provider has the assurance of a predictable and constant revenue flow known in advance. The advantage for the user is that fees are known in advance; irrespective of how many times the service is used.

Research has shown that users are generally only willing to pay for online services if the service has a direct relation with their private life (Reitsma 2007), the service fits in with their lifestyle (MRI 2012) or if users have a positive perception of convenience, essentiality, added value and service quality (Wang et al. 2005). Users are willing to pay for subscription services that are deemed essential, such as e-banking, but are less willing to pay for information services, such as online news sites, if the same information may be available free of charge via alternative channels. Therefore, a subscription-based service needs to differentiate itself by offering higher added value than alternative free services. 


\subsubsection{Utility Model}

The utility model is based on the principle of a user-pay system. Users pay each time they use a service, often per unit. Units may be time-based, volume-based or per session. This model has to be able to handle micro-payments per unit. This model is best suited to services for ad-hoc users when access to content is more important than possession of content (Welle Donker 2009). In addition, this model is only suitable to platforms where the pricing mechanisms are relatively simple, e.g., per $\mathrm{km}^{2}$, as it will become complicated to calculate the fees when combining multiple datasets with different pricing mechanisms and, thus, less transparent for the user (Fornefeld et al. 2008).

\subsubsection{Royalty Model}

In the royalty model when a product is used as a resource to develop and market value-added products, the usage-based fee depends on the success of the final product. The fee, the royalty, is typically a percentage of gross or net revenue generated by the reuser (van Loenen, Zevenbergen and de Jong 2006). The advantage of this model for the reuser is that the final fee is only payable after a value-added product is successfully marketed for a profit. The disadvantage of this model is that contracts must be exchanged in advance. In addition, if a company markets a value-added product without a profit objective, for example, a free-of-charge app, then royalties may not be payable to the data provider.

\subsubsection{Enticement Models}

These are models whereby some part is given away to lure potential customers, and the rest of the product/service is available for a fee.

\subsubsection{Razor and Blades Model}

With the "razor and blades" model, a product is supplied for free to entice the user to pay a fee for associated services. The razor is provided free of charge, the blades are provided at a cost. The free product has little value in itself and only becomes valuable with the associated services. This model may be used for creating vendor lock-in, by e.g., supplying free data in a proprietary software format (Rappa 2010). In an open data setting, Ferro and Osella (2013) call this "Infrastructural Razor \& Blades": A product/service is provided for free via APIs ("razor") while reusers are charged only for computing power that they employ on-demand in as-a-service mode ("blades"). Application of this model is limited to contexts and domains in which the computational costs are significant (Ferro and Osella 2013).

\subsubsection{Open Source Like Model}

In the open source like model a product/service is provided on top of a basic service that is provided in an open format, e.g., Linux software supplied by Red Hat. The costs of the basic 
service are covered by revenues generated by supplementary products/services that are based on open data (Ferro and Osella 2013).

Unlike the razor and blades model, the part that is given away - the data - is usable in its own right and does not require the fee-based service. This model distinguishes itself from the infrastructural razor and blades model by not being limited to a specific platform / infrastructure.

\subsubsection{Freemium / Premium Model}

The freemium/premium model, also known as versioning, uses a pricing strategy whereby a product/service - usually with a high intrinsic value - is provided in different versions (Ferro and Osella 2013). A sample or a basic version of a dataset is provided free of charge (freemium), whereas a version with a higher level of quality is provided for a fee (premium). The difference between the versions may the available size, number of available attributes, update frequency or available level of service (cf. Tennison 2012, de la Iglesia and Gayo 2009). For instance, a highly dynamic dataset may be available for a fee guaranteeing access to (near) real-time data 24/7, whereas the freemium version the data may be 24 hours old without guaranteed $24 / 7$ access.

\subsubsection{Community Model}

The community model depends on the loyalty of the users (Rappa 2010). Users invest their time and effort in developing and maintaining a specific service or platform, e.g., OpenStreetMap. The community model may also be used to facilitate user feedback to improve a data service or to improve the quality of published data (Tennison 2012) as a valuable addition to other forms of collecting data (DotEcon 2015). Revenue is raised through voluntary contributions, sales of related products and/or contextual advertisements. Companies, such as Garmin and Nike, use community platforms to obtain an insight into the usage of their products, to receive feedback and to use the sensor data (mobility patterns) generated by the platform users. This business model can be very useful for organisations that have an obligation to publish information but lack the resources to do it well (Tennison 2012).

\subsubsection{Street Performer Protocol}

In this model, a producer will release a product into the public domain after a trust fund has received a certain amount of donations. If the producer releases the product within an allocated time, the producer is paid by the trust fund. If the product is not published within the allocated time, or the product is commercially released, the donators are repaid by the trust fund (Kelsey and Schneider 1999). In an open data context, it may be conceivable that this model is deployed for co-financing the added effort to release data as open data, i.e., adapting data to anonymise personal information or corporate sensitive information.

\subsubsection{Crowd Funding Model}


Crowd funding is characterised by small donations from many individuals, mostly acquaintances (friends, family, colleagues) and, increasingly, from unknown parties. The investor may receive a small reward in return (acknowledgement on website, shares in start-up company), interest payment or the investor may donate for altruistic reasons (Zhang, Collins and Baeck 2014). With crowd funding, money is raised bypassing traditional lending organisations and often a direct relation between the donators and the funded project is created (Louzada 2013). Although crowdfunding has been used by smaller public organisations, for example, research projects ${ }^{8}$ in the United States, it is not suitable to large government agencies.

\subsubsection{Advertising Model}

Data and/or services are provided (usually, but not necessarily, free of charge) mixed with advertising messages. Revenue is generated through banner ads, intromercials and/or storing, combining and selling user registration data (Rappa 2010).

Rappa (2010) describes more advertising revenue models, such as the contextual/targeted advertising and the affiliate model (providing purchase opportunities to internet surfers). Ferro and Osella (2013) describe a "Free as Branded Advertising" model (aimed at persuading an audience towards a brand or company) and a "White Label Development" model (outsourcing required expertise to specialised firms). Although advertising models may not be suitable to all public sector organisations depending on national policies ${ }^{9}$ and/or cultural attitudes, other countries have formulated policies for advertising on government websites. ${ }^{10}$

\subsection{Summary Revenue Model}

Table 1 provides a summary of the various revenue models. All models are suitable for public sector organisations, except that the advertising model may be limited by a national legal / cultural framework. Legal instruments are only suitable to private sector organisations if they are mandated with executing a public task.

Table 1: Revenue models and their suitability for public sector organisations

\begin{tabular}{|l|l|l|}
\hline Revenue Model & Short description / options & $\begin{array}{l}\text { Suitable to } \\
\text { public sector }\end{array}$ \\
\hline Budget financing & No direct revenue raised; indirect benefits & Yes \\
\hline Legal instruments & Specific levies / taxation & Yes \\
\hline
\end{tabular}

\footnotetext{
${ }^{8}$ See for instance, http://scifundchallenge.org/blog/category/crowdfunding/

${ }_{9}^{9}$ See for instance https://www.dotgov.gov/portal/web/dotgov/program-guidelines.

10 See for instance http:/ / www.birmingham.gov.uk/advertising and www.bom.gov.au/advertising/.
} 


\begin{tabular}{|l|l|l|}
\hline & Mandatory usage of certified data products & Yes \\
\hline $\begin{array}{l}\text { Subscription } \\
\text { model }\end{array}$ & $\begin{array}{l}\text { Fees in advance for a specific period independent of } \\
\text { actual usage }\end{array}$ & Yes \\
\hline Utility model & Pay-per-use / view & Yes \\
\hline & Premium & Yes \\
\hline Royalty model & Work to order & Yes \\
\hline Enticement & (Infrastructural) razor and blades & Yes \\
\hline $\begin{array}{l}\text { model } \\
\text { model }\end{array}$ & Open Source Like & Yes \\
\hline & Freemium / premium & Yes \\
\hline $\begin{array}{l}\text { Advertising } \\
\text { model }\end{array}$ & Street performer & Yes \\
\hline & Web / banner advertising & Yes \\
\hline & Affiliation model & not always \\
\hline & Free as branded advertisement & not always \\
\hline
\end{tabular}

Organisations can employ multiple revenue models to generate income, for instance a utility model for infrequent users in combination with a subscription model for frequent users. Infrastructural razor and blades (providing an open data platform with fee-based cloudcomputing facilities) can be facilitated in combination with the open source like model (expert services to add value to open data).

\section{The Information Value Chain}

Although there is ample literature related to business models of organisations providing (open data) services, it appears that there is a tendency to use the term business model to actually describe the different activities an organisation may undertake to provide data services (e.g., Rappa 2010, Janssen and Zuiderwijk 2014), to describe the different roles an organisation may occupy in the information value chain (e.g., Malone et al. 2006, Deloitte LLP 2012), or to describe pricing mechanisms for information products (e.g., Rappa 2010; Ferro and Osella 2013). The first two aspects are part of the service component of a business model; the latter is part of the financial component. In the previous chapter, we have described the financial component of a business model. In this chapter, we will describe the service component, and specifically the roles an organisation may occupy in the information value chain. 


\subsection{Roles in the Public Sector Information Value Chain}

Public sector organisations collect and process vast quantities of raw data to information as part of their public tasks. The data are combined and transformed in multiple steps to produce the information needed to carry out these public tasks. In the information value chain, most of the costs occur in the initial stages whereas most of the value is created in the latter stages (cf. Krek and Frank 2000). We consider four activities in the information value chain: (1) collecting data, (2) aggregating and storing data, (3) processing data, including quality control and transforming into user-friendly formats, and (4) using the information product (cf. van Loenen and Zevenbergen 2010). Each step in the chain builds on the previous step and in each step, value is added to the information product. Value can be added by e.g., adding new attributes to the data or by combining with other data, e.g., data from companies, sensor data and/or crowd-sourced data. In addition, value may be added by developing tools or by supplying specialised knowledge to assist the users. The information product can be an end-product but may also be the first step of the next value chain. Figure 3 shows the information value chain for public sector data.

Figure 3: Basic information value chain with steps for adding value

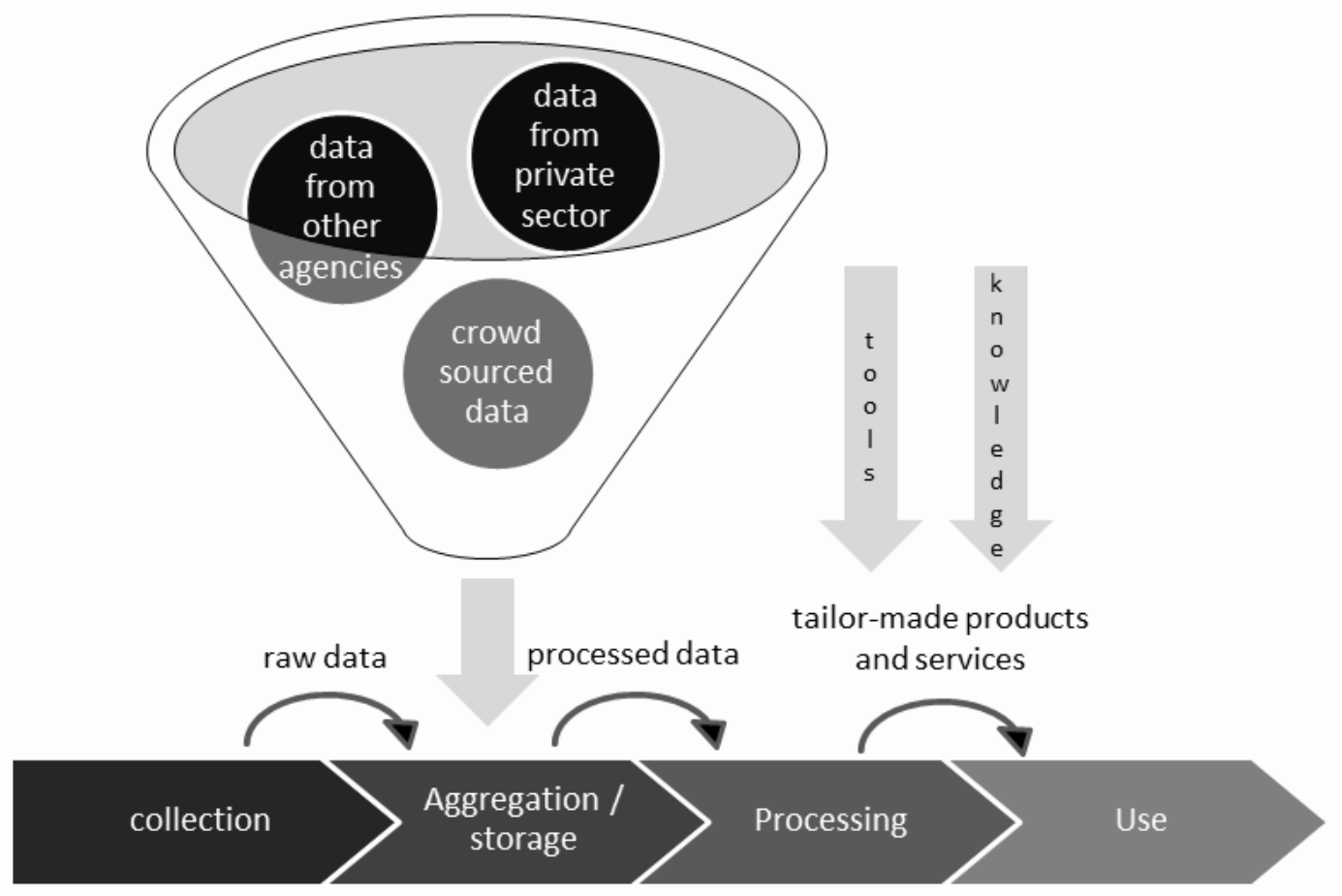

In this section, we describe the different roles in the information value chain, using the five "archetype" roles for organisations within the public sector information value chain distilled by Deloitte LLP (2012) as a basis for the Service Component. These archetype roles are:

1) Suppliers of (open) data could be public sector organisations but also companies. Data are supplied for reuse by third parties. There are no direct monetary benefits from supplying the data; instead, broader benefits could be greater transparency, enhanced reputation and/or societal benefits. 
Users of open data can be further categorised as:

2) Aggregators: Organisations that collect and aggregate open data, sometimes combined with proprietary data. Such aggregation often occurs on the sectorial or geographical level. The aggregated data could be used to present the data more efficiently or to perform analyses.

3) Enablers: Organisations that provide a platform, tools and technology for third parties to use open data. The enablers do not use the data as such but act as an intermediary between data holders and users by providing cost-effective and efficient solutions, and/or by coordinating feedback. Winning platforms are those that are more convenient, more user-friendly, better organized, and more visually appealing (Schiff 2003). In addition to providing an open data platform, enablers can offer additional services, such as consultancy. The enabler's open data platform can be a demand-oriented platform where users pay a charge for user-friendly and reliable access to data or a supply-oriented platform where the data holders pay a fee to use the enabler's resources and expertise instead of developing their own open data platform.

4) Developers: Organisations and individuals that design, develop and sell applications for end-users. Such applications, such as multi-modal route planners, typically use highly dynamic open data. Developers may sell their applications directly to end-users or build custom-made applications for other organisations.

5) Enrichers: Organisations (typically larger companies) that use open data to enhance their existing portfolio through better insight, efficiency gains or as a tool to sell other products.

End-users are at the end of the information value chain and could be the start of a new value chain. In Figure 4, we have combined the different roles identified by Deloitte LLP (2012) and activities as part of the public sector information (PSI) value chain. 
Figure 4: The roles and activities identified by Deloitte LLP (2012) and their relation to the PSI value chain
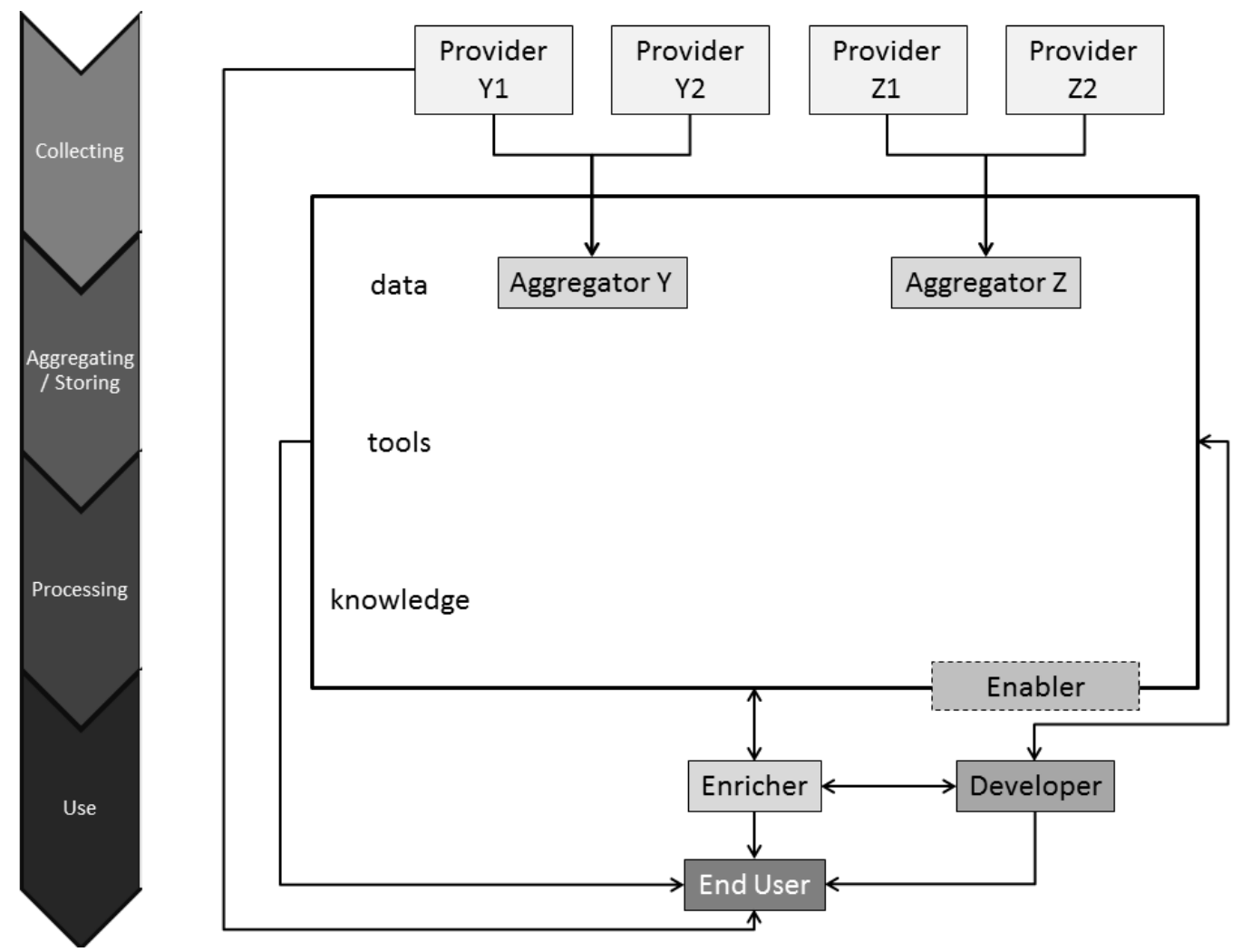

\subsection{Service Component Linked to Financial Component}

In the previous chapter, we have described which revenue models are appropriate for public sector organisations. In this section, we link the five roles for public sector bodies in data processing to the financial component.

1) Supplier: Activities are financed by budget financing, legal instrument charges or in combination with additional fee-based services, e.g., to use freemium/ premium model to generate revenue from high value information.

2) Aggregator: Can adopt different revenue models, e.g., access via APIs ${ }^{11}$ free of charge and fee-based services for combining data from other sources. Aggregators can also be financed by budget financing and/or legal instrument charges.

3) Developer: Generate revenue by working to order or from sales of applications, using the subscription model, the utility model and/or advertising models. It is conceivable that a developer may use crowd funding.

4) Enabler: Generate revenue directly from the use of the platform and/or supplementary information services. Combination of almost all revenue models can be used by the Enabler,

\footnotetext{
11 Application programming interface (API) is a set of routines, protocols, and tools for building software applications, i.e., the building blocks of a computer programme.
} 
depending on the status of the organisation (public, private) and the types of supplementary services. In addition, operational expenses may be reduced due to efficiency gains.

5) Enricher: Often use open data to improve existing products/service. Revenue is generated by efficiency gains and/or added value for existing customers by facilitating effective use of existing products/services. The revenue models that are already in place will probably not be adapted.

Table 2 shows the relation between the different roles and revenue models. A plus indicates that the revenue model is suitable to both the public sector and the private sector. A hyphen indicates that the revenue model is only suitable to public sector organisations (and private organisations mandated with carrying out a public task). A cross indicates that the revenue model is suitable to the private sector but not always to the public sector, depending on the legal and cultural framework.

Table 2: Relation between roles and revenue models, and suitability to public sector and private sector.

\begin{tabular}{|c|c|c|c|c|c|c|c|c|}
\hline IVodel & 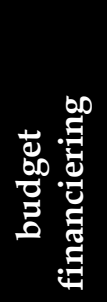 & 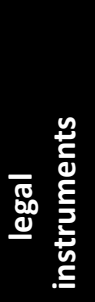 & 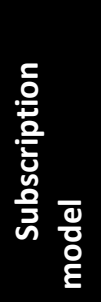 & 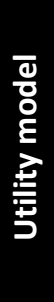 & $\begin{array}{l}\overline{0} \\
\frac{0}{0} \\
\text { ह } \\
\frac{7}{0} \\
\frac{0}{0} \\
\frac{0}{\alpha}\end{array}$ & 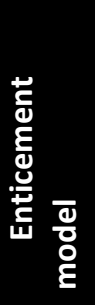 & 胥 & 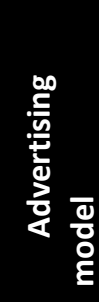 \\
\hline Supplier & + & - & + & + & + & + & + & $x$ \\
\hline Aggregator & + & - & + & + & + & + & + & $x$ \\
\hline Developer & + & - & + & + & + & + & + & $x$ \\
\hline Enabler & + & - & + & + & + & + & + & $x$ \\
\hline Enricher & + & - & + & + & + & + & + & $x$ \\
\hline legend: & $\begin{array}{l}+= \\
-= \\
x=\end{array}$ & able $t$ & $\begin{array}{l}\text { ublic se } \\
\text { to pub } \\
\text { civate } \mathrm{s}\end{array}$ & $\mathrm{rbu}$ & $\begin{array}{l}\text { ate } \\
\text { hot } \\
\text { lwa }\end{array}$ & $\begin{array}{l}\text { s to p } \\
\text { publi }\end{array}$ & $\begin{array}{l}\text { ate sec } \\
\text { ector }\end{array}$ & \\
\hline
\end{tabular}

\section{Case Studies}

\subsection{Methodology}

Having to implement an open data policy, may create a financial burden for government agencies that rely on generating revenue to cover a substantial part of their operating costs - so-called selffunding agencies. There may be a risk that revenue losses due to open data may endanger the agency's ability to maintain operations at a sustainable level and with an adequate level of quality. To test this hypothesis, we have researched the effects of open data on the business model of a number of self-funding agencies in the Netherlands and the United Kingdom, and a budgetfinanced agency in Australia.

To examine which open data business models would be suitable for (long-term) sustainability for self-funding government organisations, we analysed the current business model of four Dutch 
organisations by desk research and by face-to-face interviews. The cases were selected because these organisations are by law allowed to charge fees for reuse of their data. All four organisations are key register data administrators and are, therefore, monopolists for these authentic datasets. Although these self-funding organisations rely on income from fee-based services to cover a substantial part of their operating costs, they are also under pressure to supply key register data as open data. For comparison, we analysed the business model of two open data government agencies outside the Netherlands. These cases were selected from a shortlist of best practice cases after a literature review. The research for the international cases was carried out by desk research and interviews by phone. All interviews were structured, using open questions sent to the interviewees before the interview. Additional desk research was carried out by analysing annual reports and information available from the websites of the interviewed organisations. Reports of the interviews were sent to the interviewees for validation.

\subsection{Dutch National Transport Agency (RDW)}

The Dutch National Transport Agency (RDW) is a self-funding government agency of the Ministry of Infrastructure and the Environment and is responsible for registering the life cycle of motorised vehicles, including a number plate register. In addition, the RDW is responsible for registering driver's licences and annual vehicle tests. The RDW is the managing authority for the Key Register Vehicles.

\subsubsection{RDW Service Component}

Since 2013, the RDW supplies part of its registers as open data. These data are:

1) General vehicle data, such as make and model, fuel consumption and registration history. Reports of missing and/or stolen vehicles are not available as open data. The update frequency is daily. A request may contain 1 to 100 number plate registrations.

2) Parking data: static data pertaining to parking areas and corresponding parking fees, and near real-time data pertaining to availability of municipal and commercial parking areas.

The RDW also supplies similar data as a fee-based web service (OVI-business) with a higher service level: available as near real-time data, no data limit, and additional historical information available. OVI-business guarantees 24/7 availability through a Service Level Agreement.

\subsubsection{RDW Financial Component}

The RDW receives no budget financing from the national government or compensation for open key register data. Operational costs are covered by revenue received from vehicle registration charges and annual vehicle tests. Open data supply is financed by internal budget allocations.

The RDW receives revenue from the private sector for their fee-based services. The total revenue in 2014 was $€ 193.4 \mathrm{M}$ (RDW 2015, p.87) with revenue from information dissemination accounting for just over $2 \%$ of the total revenue. Compared to 2012, revenue from information products, especially from the vehicle traders, dropped in 2014 from $€ 4.86$ to $€ 4.11 \mathrm{M}$ (RDW 2015, 
p.87). According to the RDW interviews, the loss of revenue is offset by internal efficiency gains and fewer data requests.

\subsubsection{Summary RDW Business Model}

The RDW employs legal instruments (registration fees and annual vehicle test charges) to cover their operational costs. The revenue model is a combination of freemium/premium: (downgraded) open data with a lower service level and fee-based data available as a subscription-based addedvalue service. The RDW has not developed additional value-added services to compensate for revenue losses due to open data. Open data have not had a significant impact on the revenue of fee-based services: after an initial drop, RDW actually received more applications for fee-based data services as more users became aware of the data potentials. Since the introduction of open data, the prime role of the RDW in the information chain has moved from Aggregator towards Enabler by offering a limited number of tools for open data. The RDW did not develop these tools themselves; instead, they opted to use an existing platform (MS Azure) with a proven track record.

\subsection{Dutch Cadastre, Land Registry and Mapping Agency (Kadaster)}

The Dutch Cadastre, Land Registry and Mapping Agency (Kadaster) is a self-funding nondepartmental public body operating under the responsibility of the Ministry of Infrastructure and the Environment. One of its statutory tasks is to manage four key registers (Key Register Topography, Key Register Cadastre, Key Register Real Estate Values and Key Register Large Scale Topography), as well as to manage datasets on behalf of the Ministry. In addition, the Kadaster manages the national geographic information platform PDOK. This case study is limited to the Kadaster's open data, the Key Register Topography.

\subsubsection{Kadaster Service Component}

The Key Register Topography (BRT) consists of digital topographic data in various formats and scales, including 1:10,000 and has been available as open data since 1 January 2012. The BRT is available via web viewing services and download services from the PDOK platform. It is mandatory for other government bodies to use BRT data for their public tasks unless the data do not meet their specific needs. The introduction of BRT open data has led to a rapid increase in reuse and an increased demand for better actuality. The Kadaster has started a project to provide a user-friendly feedback system open to parties outside the public sector to improve the data quality (Grus and te Winkel 2015).

\subsubsection{Kadaster Financial Component}

The Kadaster nett turnover was $€ 257.6 \mathrm{M}$ in 2014, of which 5\% came from topography (nonstandard products) (Kadaster 2015, p.73).

Before open data, revenue from topographic data accounted for $8 \%$ (€21M) of the total turnover (Kadaster 2012, p.96). To offset the loss in revenue, the national government pays compensation to 
the Kadaster, which covers about $50 \%$ of the BRT operating costs. The other $50 \%$ are expected to be covered by efficiency gains, such as staff reduction and increased data quality (de Vries 2014). The annual compensation has decreased since 2013 due to government budget cuts (Kadaster 2015). In addition to other forms of revenue, Kadaster manages PDOK, set up as a Supply-Oriented platform where other public organisations pay per dataset to host data.

\subsubsection{Summary of Kadaster Business Model}

Before open topographic data, the Kadaster's prime role in the information chain was Aggregator by using a combination of legal instruments, subscription model and utility model. For non-open data, the Kadaster still uses the same revenue models. The Kadaster receives some budget financing to compensate reuse within the public sector. The Kadaster has started to experiment with the community model (wisdom of the crowd) to provide feedback on the data quality. The Kadaster's secondary role in the information chain is Enabler by developing tools and offering specialist knowledge for its own consultancy and support services, and as developer and manager of PDOK. Although its revenue models have changed due to open topographic data, the Kadaster's role in the information chain was already shifting from Aggregator to Enabler, due to its role in managing PDOK.

\subsection{TNO Research Institute}

TNO, the Netherlands Organisation for Applied Scientific Research is a self-funding independent research institute mandated with carrying out a number of public tasks. One of its public tasks as the Netherlands Geological Survey is to maintain the Key Register Soil and Subsurface Data.

\subsubsection{TNO Service Components}

Under the Mining Act, it is compulsory for public and private organisations to supply TNO with subsurface data collected by these organisations. TNO has developed subsurface data models for its data platform as a way of presenting the data in a more user-friendly way. The data and data models are available as open data. Drilling and probing data are used for large-scale building projects whereas reuse for small-scale building projects and for non-archaeological purposes has been almost zero (Twynstra Gudde, CE Delft and Tauw 2011). TNO employs a cost recovery regime to provide specialised research and services based on geological data.

\subsubsection{TNO Financial Component}

There are few figures available related to data dissemination. The data management costs for TNO are estimated at $€ 4.8 \mathrm{M}$ for the period $2011-2025+€ 0.3 \mathrm{M}$ per annum for non-personnel related expenditure (Twynstra Gudde et al. 2011), which constitutes less than 1\% of the total operational costs of $€ 533.6 \mathrm{M}$ in 2014 (TNO 2015, p.42). 


\subsubsection{Summary TNO Business Models}

TNO's prime role in the information chain is Aggregator by using legal instruments (Mining Act). There is no need to generate revenue from subsurface data as the operational data costs are low compared to TNO's total operational costs. TNO's secondary role in the information chain is Enabler by developing tools and data models to present the subsurface data in a more userfriendly way. TNO employs an Open Source Like model by offering its knowledge to provide specialised geological services and research.

\subsection{Dutch Chamber of Commerce}

The Dutch Chamber of Commerce (Kamer van Koophandel $(\mathrm{KvK})$ ) is a self-funding agency of the Ministry of Economic Affairs. Its core tasks are to register, inform and advise companies and to maintain the Key Trade Register. The Key Trade Register contains data related to companies, e.g., business profile, history and deposited documents. Incorporation is mandatory for all companies and legal entities. Companies require authenticated copies of registration for a number of business transactions, e.g., for bank loan applications. It is mandatory for other government bodies to reuse data from the Key Trade Register, e.g., to register a company in the Key Register Cadastre, the Kadaster must refer to the Key Trade Register.

\subsubsection{Kamer van Koophandel Service Component}

The Kamer van Koophandel $(\mathrm{KvK})$ provides a free viewing service for accessing the public part of Key Trade Register data only, i.e., name, street address and website address of a company per single entry. The KvK deems other Key Trade Register data to be non-public, i.e., to be privacysensitive data and commercially-sensitive data. The KvK provides a fee-based service for companies to obtain an authenticated copy of incorporation, and provides various services for additional (non-public) information, such as lodged annual reports, company address data, mutation subscriptions, and data integration services. Bulk products are available for one-off fees and/or subscription fees. The KvK offers advice and information services for companies. The KvK is in the process of improving their fee-based online services by developing apps, APIs and valueadded services combining Trade Register data with data from other sources.

\subsubsection{Kamer van Koophandel Financial Component}

In 2014, the total income of the $\mathrm{KvK}$ was $€ 218.5 \mathrm{M}$ with a net loss of $€ 63.1 \mathrm{M}$, mainly due to high reorganisation costs and decreased revenue from information products (Kamer van Koophandel 2015, p.52). In 2012, the national government abolished annual company registration fees to reduce the administrative burden of companies. In addition, government bodies no longer pay each time they reuse Key Trade Register information. Instead, the national government pay an annual compensation to the KvK, which amounts to about sixty percent of the KvK's revenue. This annual contribution will be reduced from $€ 134.9 \mathrm{M}$ in 2014 to $€ 114.8 \mathrm{M}$ in 2015 (Kamer van Koophandel 
2015 , p.51). KvK activities generated net $€ 35.8 \mathrm{M}$ in 2014 , of which $8.7 \%$ (€3.1) was generated by selling information products.

Should (part of) the Key Trade Register become available as open data (depending on various levels of data protection), it is expected that usage of the services will increase but revenue will drop between $€ 7.9 \mathrm{M}$ to $€ 38.9 \mathrm{M}$, depending on which data will become available as open data. It is expected that the estimated net loss in revenue will be limited to circa $€ 0.75 \mathrm{M}$ per annum due to increased internal efficiencies (Verdonck Klooster \& Associates, Ecorys and Berenschot 2014, p.26). Open data could help to increase the level of data quality, as more people will be able to report data errors.

\subsubsection{Summary of Kamer van Koophandel Business Model}

The KvK's prime role in the information chain is Aggregator by using a combination of legal instruments (incorporation fees), budget financing and data services using subscription model and utility model to generate revenue. In addition, the $\mathrm{KvK}$ offers specialist knowledge for consultancy and support.

The $\mathrm{KvK}$ recognises that its current business model is under threat (Kamer van Koophandel 2015, p.55). It has to cope with revenue reductions due to the abolition of annual registration fees and budget cuts by the central government. After the Trade Register became part of the key register system, companies are no longer required to obtain a paper-based authenticated proof of registration from the KvK for many other government transactions, such as registering a company car, thus, further eroding the revenue base of the $\mathrm{KvK}$. As the $\mathrm{KvK}$ is also under pressure to release at least some of its data for reuse as open data, the KvK must find additional sources of revenue.

\subsection{Australian Bureau of Statistics (ABS)}

The Australian Bureau of Statistics (ABS) is Australia's official statistical organisation. In 2005, the ABS made its statistical data available as open data.

\subsubsection{ABS Service Component}

The ABS provides Australian national statistics, key economic indicators, census data, consumer price index, labour force, national accounts, regional statistics, and measures of Australia's progress. The ABS provides the following statistical products / services:

- ABS information in the basic set, available on the ABS website free of charge

- Self-service tools for generating statistical tables from a variety of data sources

- Self-service statistical literacy resources via the ABS website free of charge

- National Information and Referral Service (NIRS) providing free information over the phone for straightforward enquiries.

The ABS supplies printed publications, information consultancy services, selected Census products and Confidentialised Unit Record Files (CURFs) for a fee. 
The ABS has developed value-added services based on its statistical data, as there is a demand for such products and services, especially from the education sector. The ABS would prefer the private sector to take up the development of value-added services; however, the private sector appears reluctant to fill the gap.

Since the introduction of open data, there has been a significant increase in web service traffic and in the types of users. Open data require a higher level of data quality and metadata quality as errors become visible for everybody. There has been a decrease in the number of e-mail inquiries and sales of hard copy publications.

Consultancy services have grown slightly every year instead of dropping after the introduction of open data, especially for complex work and specialised services. By offering free data, people have become more aware of the benefits and opportunities of statistics but do not always have the skills to analyse the statistical data.

\subsubsection{ABS Financial Component}

Data customised to meet specific user needs are available for a fee. The ABS must recover costs associated with preparing customised requests for individual clients / organisations in accordance with government cost-recovery guidelines. Costs are also recovered for training, consultancies, providing paper copies of ABS publications, information on CD-ROM and access to data via specialised products such as Census DataPacks, TableBuilder and CURFS. In all cases where costs are recovered, the ABS will charge "efficient costs" i.e., the minimum costs necessary to deliver products and services that are fit for purpose. ${ }^{12}$

The ABS is wholly funded by the national government. In 2005, revenue from data was relatively low to the annual costs (6.9\%). In 2013/14, sales of product and services accounted for $10.9 \%$ of the total budget (Australian Bureau of Statistics 2014, p.133).

\subsubsection{Summary ABS Business Model}

Prior to 2005, the ABS was primarily an Aggregator employing a combination of budget financing and premium products as revenue models. After 2005, the revenue models of the ABS have shifted to a combination of budget financing and Open Source Like. The Open Source Like revenue model was not a deliberate choice but rather a consequence of open data. By providing open data, consultancy activities have increased. The role of the ABS has shifted to the Enabler role as the ABS provides tools to facilitate use of their data services in a more effective way. Open data is used as a way of applying the knowledge of ABS to provide specialised statistical services.

\footnotetext{
${ }_{12}^{12 h t t p: / / w w w . a b s . g o v . a u / w e b s i t e d b s / d 3310114 . n s f / 51 c 9 a 3 d 36 e d f d 0 d f c a 256 a c b 00118404 / 12 b b 13 b 927110 e 4 ~}$ 4ca2569a80013bec1!OpenDocument.
} 


\subsection{UK Companies House}

The UK Companies House ( $\mathrm{CH}-\mathrm{UK})$ is an Executive Agency of the Department for Business, Innovation and Skills. CH-UK has Trading Fund status, i.e., it is a self-funding agency directly managing its own finances and having to pay an annual dividend to the national government. The core tasks of $\mathrm{CH}-\mathrm{UK}$ are to incorporate and dissolve limited companies, examine and store company information delivered under the Companies Act and related legislation; and make this information available to the public. CH-UK also carries out delegated functions for the Secretary of State, for example, enforcing the delivery of annual accounts and annual returns and directing companies to change their names when these are similar to those currently on the public record, et cetera.

\subsubsection{UK-CH Service Component}

UK-CH currently offers a number of data services. Two of these data services are free of charge; the other data services are available for a subscription fee and/or pay-per-use fee. These services of UK-CH are:

- WebCHeck service providing a searchable Company Names and Address Index (free of charge). An app providing access to basic company details, register statistics and warnings when certain reports are due to UK-CH (free of charge).

- WebFiling service allowing companies to submit information and reports electronically, and download Incorporation Certificates.

- WebCHeck to view the filing history of a company, purchase copies of document images and a selection of company reports.

- Companies House Direct (CHD), a subscription service allowing access to all UK-CH records, including analogue records.

$\mathrm{CH}-\mathrm{UK}$ also produces DVD and bulk data products of their directory on demand.

As part of improving internal efficiencies, the UK-CH is developing new services and/or improving existing services to replace the WebFiling, WebCheck and $\mathrm{CH}$ Direct services. Since 25 June 2015, CH-UK operates a beta service providing open data access and download facility to digital records on companies and directors per single entry.

$\mathrm{CH}-\mathrm{UK}$ does not intend to produce value-added products and services using its data as a resource, as this should be done by the private sector or anybody in the market.

\subsubsection{CH-UK Financial Component}

As a trading fund, $\mathrm{CH}-\mathrm{UK}$ is required to generate a surplus at the end of the financial year and pay a dividend to the Ministry, amounting to $£ 4.4 \mathrm{M}$ in 2015 . The main sources of CH-UK's income are incorporation fees and annual contributions. In addition, $\mathrm{CH}-\mathrm{UK}$ receives revenue from dissemination activities. $\mathrm{CH}-\mathrm{UK}$ uses a combination of a subscription model and utility model for dissemination services. The switch to open data services is financed out of its own budget. 
$\mathrm{CH}-\mathrm{UK}$ employs a full cost recovery regime for its operations. The total income out of fees and charges was $£ 67.5 \mathrm{M}$ in $2014 / 15$. Revenue from dissemination activities was $£ 10.4 \mathrm{M}$. Dissemination activities account for $15 \%$ of operating income, registration activities for $83 \%$ and other services account for $2 \%$ (Companies House 2015, p.45). At this stage, it is too early to assess the full impact of open data.

\subsubsection{Summary $\mathrm{CH}-\mathrm{UK}$ Business Model}

$\mathrm{CH}-\mathrm{UK}^{\prime}$ 's prime role is Aggregator of data provided by companies and generates revenue with legal instruments (compulsory incorporation fees and annual contributions) and premium data products.

In the last two years, the $\mathrm{CH}-\mathrm{UK}$ is moving towards an Enabler role by developing tools to facilitate use of (open) data in a more effective way as part of an internal efficiency drive. $\mathrm{CH}$-UK does not use its raw data to provide advisory services or value-added products.

\subsection{Summary Case Studies}

The ABS is wholly funded by the government and made the switch to open data a decade ago. The self-funding agencies use a combination of legal instruments and fee-based data services to cover their operational costs. The Kadaster and the Dutch Chamber of Commerce receive additional budget financing to partially compensate free use of key register data within the public sector. Most researched agencies use hybrid revenue models combining open data with fee-based subscription and utility services. In addition, most of the agencies have developed tools to facilitate users and/or are offering their expert knowledge as (fee-based) value-added services. The Kadaster has an additional revenue base as the manager of PDOK, the supplier-driven platform for geographic data.

To date, the effects of open data have been a decrease in revenue from information products and an increase in data traffic. However, as the revenue constituted a relative small part of the total revenue, the losses appear to be offset by internal efficiency gains and higher data quality. The datasets that are not (yet) available as open data often represent a larger part of the total turnover. Table 3 provides a summary of the financial component of the researched business models and the reported effects of open data.

Table 3: Summary financial components of case studies

\begin{tabular}{|l|l|l|l|l|l|}
\hline & $\begin{array}{l}\text { Total } \\
\text { revenu } \\
\text { e in in } \\
\mathbf{2 0 1 4} \\
(€ \mathbf{M})\end{array}$ & $\begin{array}{l}\text { Data } \\
\text { revenue } \\
\text { before } \\
\text { open data } \\
(\mathbf{\%} \quad \text { of } \\
\text { total) }\end{array}$ & $\begin{array}{l}\text { Data } \\
\text { revenue } \\
\text { after } \\
\text { open data } \\
\left(\begin{array}{l}\% \quad \text { of } \\
\text { total) }\end{array}\right.\end{array}$ & Revenue model & Effects of open data \\
\hline RDW & 193.4 & $2.6 \%$ & $2.1 \%$ & $\begin{array}{l}\text { - Legal } \\
\text { instruments } \\
\text { - Freemium }\end{array}$ & $\begin{array}{l}\text { - Increase in requests } \\
\text { - Increase of requests for } \\
\text { additional services }\end{array}$ \\
\hline
\end{tabular}




\begin{tabular}{|c|c|c|c|c|c|}
\hline & & & & $\begin{array}{l}\text { Premium } \\
\text { services }\end{array}$ & $\begin{array}{l}\text { - Increase in fee-based } \\
\text { premium services } \\
\text { - Increase in feedback / } \\
\text { reporting errors } \\
\text { - Decrease in internal } \\
\text { transaction costs } \\
\text { - New applications developed } \\
\text { by third parties } \\
\text { - Operational costs reduced by } \\
\text { using existing infrastructure }\end{array}$ \\
\hline Kadaster & 257.6 & $8 \%$ & $5 \%$ & $\begin{array}{l}\text { - Legal } \\
\text { instruments } \\
\text { - Budget financing } \\
\text { - Supply-driven } \\
\text { platform } \\
\text { (PDOK) }\end{array}$ & $\begin{array}{l}\text { - Increase in use, especially by } \\
\text { citizens } \\
\text { - Decrease of requests via } \\
\text { Kadaster directly } \\
\text { - Increase in requests via PDOK } \\
\text { - Increase in feedback / error } \\
\text { reports } \\
\text { - Increased demand for better } \\
\text { actuality of data } \\
\text { - Decrease in transaction costs } \\
\text { internally and externally } \\
\text { - New applications developed } \\
\text { by third parties } \\
\text { - Operational costs reduced by } \\
\text { - using existing infrastructure } \\
\text { - Decrease in revenue } \\
\text { budget funding }\end{array}$ \\
\hline TNO & 533.6 & $<1 \%$ & $\begin{array}{l}\text { Not } \\
\text { available }\end{array}$ & $\begin{array}{l}\text { - Legal } \\
\text { instruments } \\
\text { - Open Source } \\
\text { Like }\end{array}$ & $\begin{array}{l}\text { - Increase in use for } \\
\text { construction works } \\
\text { - Increase in use for agriculture } \\
\text { (groundwater data) } \\
\text { - Development of tools and } \\
\text { models } \\
\text { - Operational costs reduced by } \\
\text { using existing infrastructure }\end{array}$ \\
\hline $\begin{array}{l}\text { Dutch } \\
\text { Chamber } \\
\text { of } \\
\text { Commerc } \\
\text { e }\end{array}$ & 218.5 & $3.7 \%$ & $\begin{array}{l}\text { Not } \\
\text { applicable }\end{array}$ & $\begin{array}{l}\text { - } \text { Budget financing } \\
\text { - Legal } \\
\text { instruments } \\
\text { - Subscription } \\
\text { model } \\
\text { - Utility model }\end{array}$ & $\begin{array}{l}\text { Free viewing service: } \\
\text { - Increase in company searches } \\
\text { for basic data } \\
\text { - Decrease in revenue } \\
\text { - Increased dependency on } \\
\text { budget funding }\end{array}$ \\
\hline $\begin{array}{l}\text { Australian } \\
\text { Bureau of } \\
\text { Statistics }\end{array}$ & 353.1 & $6.9 \%$ & $10.9 \%$ & $\begin{array}{l}\text { - Budget financing } \\
\text { - Open source like }\end{array}$ & $\begin{array}{l}\text { - Increase in requests / } \\
\text { downloads, etc. } \\
\text { - Increase of requests for }\end{array}$ \\
\hline
\end{tabular}




\begin{tabular}{|c|c|c|c|c|c|}
\hline & & & & & $\begin{array}{l}\text { consultancy services } \\
\text { - Increase in fee-based } \\
\text { premium services } \\
\text { - Increase in feedback / } \\
\text { reporting errors } \\
\text { - Decrease in internal } \\
\text { transaction costs } \\
\text { - New tools developed by ABS }\end{array}$ \\
\hline $\begin{array}{l}\text { Companie } \\
\text { s House - } \\
\text { UK }\end{array}$ & $96.8^{13}$ & $20 \%$ & $15.4 \%$ & $\begin{array}{l}\text { - Legal } \\
\text { instruments } \\
\text { - Subscription } \\
\text { model } \\
\text { - Utility model }\end{array}$ & $\begin{array}{l}\text { - Increase in company searches } \\
\text { \& downloads } \\
\text { - Decrease in requests via other } \\
\text { channels } \\
\text { - Decrease in revenue } \\
\text { - Decrease in internal and } \\
\text { external transaction costs }\end{array}$ \\
\hline
\end{tabular}

Figure 5 shows the shift in roles for the researched agencies. The Chamber of Commerce does not provide open data. Its role is very slowly shifting down from Aggregator. The other agencies have shifted further from Aggregator towards Enabler since providing open data. The Kadaster has made the biggest shift as manager of PDOK. 
Figure 5: Shift in roles in the PSI chain for the researched agencies after introduction of open data
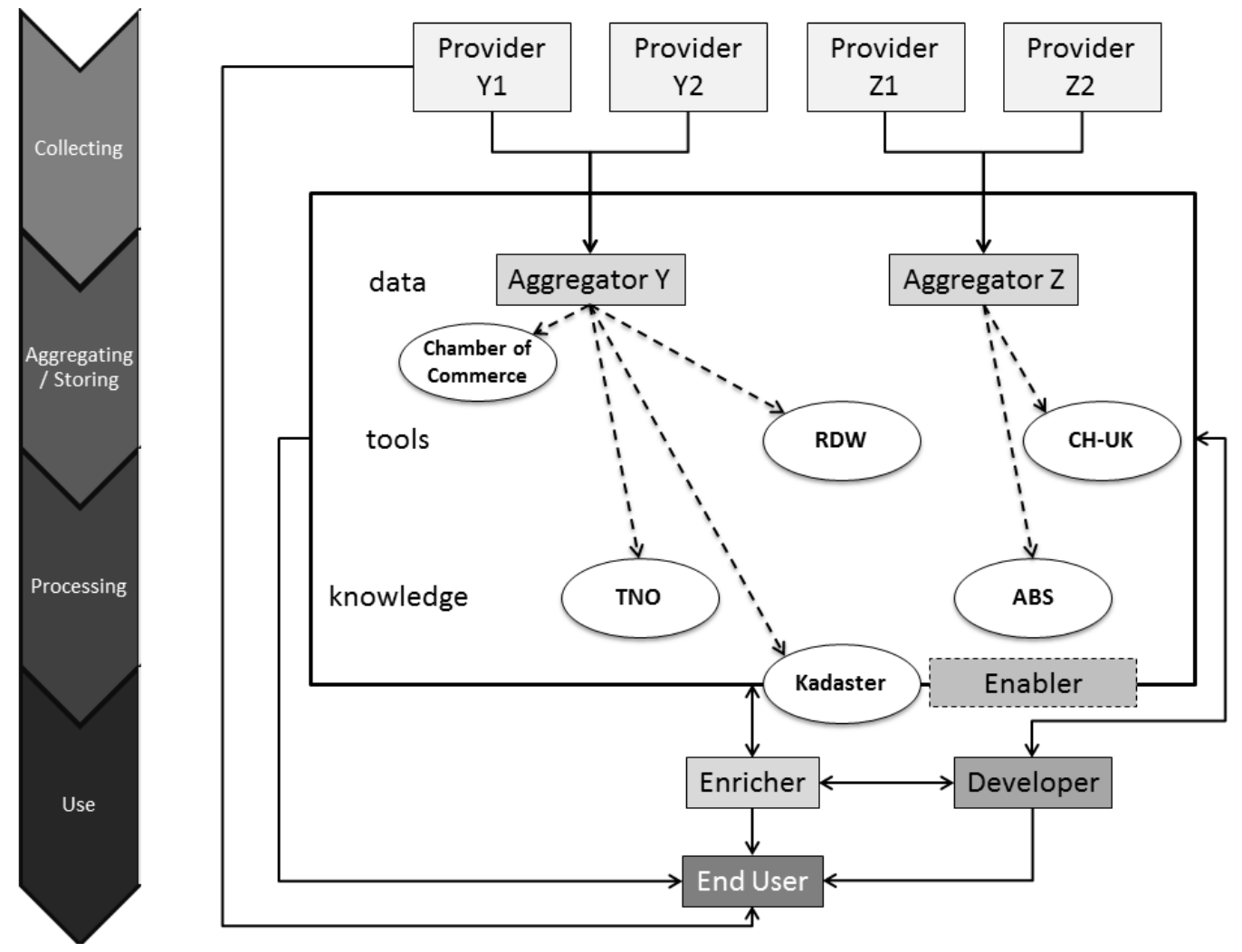

\section{Analysis and Conclusions}

\subsection{Case Study Findings}

This article has researched business models that may be suitable for self-funding government agencies that are considering or are in the process of implementing open data policies. We have researched alternative and innovative business models to find out if these business models can be adopted or adapted. We have analysed the business model of a number of government agencies that have already made the transition to open data, and one agency that is under pressure to provide (some) open data in the near future. Our case studies demonstrate that business models have adapted to ensure the long-term availability of high quality open data, thus addressing longterm financial sustainability of the agencies.

The case studies have shown that providing (raw) open data will not necessarily lead to losses in revenue in the long term. Where organisations have implemented open data in addition to feebased services, there have been no negative effects on the fee-based services. It should be stressed though, that in all open data cases, revenue generated by fee-based services are relatively low when compared to the main source of income (budget-financed and/or legal instrument model) and the revenue is independent from the main source of revenue. In a number of cases, revenue from fee-based services has even increased. From interviews and from business analytics it emerged that open data has led to internal efficiency gains. In practice, it is difficult to quantify 
internal efficiency gains solely due to open data in isolation as the researched organisations continuously implement measures to increase efficiency. However, the reported decreases in internal and external transaction costs due to open data are in line with other research (cf. de Vries et al. 2011, Houghton 2011, Koski 2015). An open data case study of a private sector energy network administrator in the Netherlands resulted in similar findings (Welle Donker, van Loenen and Bregt 2016).

Our research suggests that open data results in new roles in the information value chain. Before open data, organisations were primarily Aggregators of (raw) data; now they are moving towards the Enabler role by developing tools and/or platforms to facilitate users. Often, these tools / platforms are developed to provide data in a more user-friendly way. In some cases, expert knowledge is offered as a fee-based value-added service.

Where open data are not available, the business models are more uncertain as demonstrated by the Dutch Chamber of Commerce. Its revenue from information products and budget financing has decreased whilst operating costs have increased due to a reorganisation. Its business model becomes even more uncertain as one the one hand, a Bill is drafted that will allow stricter data control to protect the Chamber of Commerce's revenue base in the future, whilst on the other hand, there is strong pressure from society and from members of parliament to release Key Register data as open data. The UK Companies House demonstrates that open data may actually be more beneficial in the longer run; however, its revenue base from legal instruments is higher and more stable than that of their Dutch counterpart.

\subsection{Theory versus Reality}

Based on a literature study, we have identified a number of potential revenue models. In practice, the case studies have shown that government organisations use the following revenue models:

- Budget financing (Kadaster, $\mathrm{KvK}, \mathrm{ABS}$ )

- Legal instruments / compulsory contributions (RDW, Kadaster, TNO, KvK, CH-UK)

- Freemium / premium (RDW)

- Open Source Like (TNO, ABS)

The researched cases have demonstrated that it is vital for a sustainable open data business model to have a guaranteed main source of revenue, whether it be budget financing or access to legal instruments for levying charges. The researched cases have also demonstrated that offering open data without additional tools are not sufficient to ensure effective use of the data. Thus, all researched organisations have moved from Aggregators towards Enablers in varying degrees. Of the researched organisations, only RDW reused an existing platform and tools for open data supply. All other organisations have developed their own open data platform and tools.

Government agencies that are in the process of implementing open data should analyse their current role in the information value chain, and which role the organisation can / would like / is allowed to move towards. The role in the information value chain determines which level of services (data services, tools, knowledge) are to be provided and whether to develop these services 
and tools themselves or to use external developers. Once the role in the value chain has been determined, the most optimal revenue model(s) that are appropriate can be adopted, allowing flexibility to cope with a dynamic economic and political landscape. Such choices will depend on the legal framework and the available resources. However, there is no one-size-fits-all sustainable open data business model.

We have found sustainable business models for open data, but in each case, these were unique. There are still a number of issues to be considered. Firstly, open data do not necessarily imply additional open/free services. Secondly, there are many different users and different user needs. Freemium / premium services can address the variety in user needs, such as constant access to near real-time data. Our case studies indicate that some users actually prefer paying for a guaranteed service level. Thirdly, to implement open data in a user-friendly way requires investments. Such investments may provide a return on investment, such as efficiency gains or more feedback on data quality. However, in practice it proves difficult to quantify the direct benefits of open data.

\subsection{Further Research}

Open data is still in its infancy and the actual benefits of open data still have to materialise. However, measuring the benefits of open data is no mean feat. Our research indicated that initially such benefits may be found in internal efficiencies for organisations. However, more case studies are needed to quantify the (longer-term) effects on self-funding agencies and to verify our model.

Our research indicates that for sustainable business models, it is a key to be able to move in the information value chain. However, more research is needed to confirm our initial findings. This research has demonstrated that each agency employs its own strategies and develops its own platforms/tools to publish open data. To ensure the long-term viability of open data platforms, a governance framework should be developed which addresses not only aspects, such as long-term finances and commitments to manage these platforms, but also technical aspects, such as data interoperability, to ensure efficient reuse by third parties requiring data from multiple platforms. More research is needed to formulate good governance of open data especially to guarantee the long-term availability.

\section{References}

Australian Bureau of Statistics (2014). Annual Report 2013-14. Canberra. Retrieved September 23, 2014, from http://www.ausstats.abs.gov.au/ausstats/subscriber.nsf/0/0BCB69DE782667DACA257D7200114E5D /\$File/abs_annual_report_2013_14_web.pdf.

Bouwman, H., T. Haaker and H. de Vos (2008). Mobile service innovation and business models. Heidelberg: Springer Verlag.

Companies House (2015). Companies House Annual Report and Accounts 2014/15, Retrieved July 27, 2015, from 
https://www.gov.uk/government/uploads/system/uploads/attachment_data/file/446159/Annual_ Report_201415.pdf.

de la Iglesia, J.L.M. and J.E.L. Gayo (2009). Doing business by selling free services. In M.D. Lytras, E. Damiani and P. Ordóñez de Pablos (eds), Web 2.0. The business model, pp 89-102. New York: Springer.

de Reuver, M., H. Bouwman and T. Haaker (2008). Capturing value from mobile business models: Design issues that matter. 21st Bled eConference eCollaboration: Overcoming boundaries through multichannel-interaction, Bled, Slovenia. Retrieved October 7, 2010, from http://domino.fov.unimb.si/proceedings.nsf/Proceedings/9D94EC6E7C9E47D2C1257481003D8ECF/\$File/09Reuver.pdf.

de Vries, M. (2014). Wah kos'dah dan? Onderzoek naar de incrementele kosten van aan Open Data doen [What's it going to cost? Research on the incremental cost of doing Open Data]. The Green Land. Retrieved March 4, 2014, from http://open-overheid.nl/open-overheid/open-data-wah-kos-dah-dan/.

de Vries, M., L. Kapff, M. Negreiro Achiaga, P. Wauters, D. Osimo, P. Foley, K. Szkuta, J. O'Connor and D. Whitehouse (2011). Pricing of Public Sector Information Study (POPSIS) - Summary Report. Brussels: Deloitte Consulting CVBA,, Retrieved February 29, 2016, from https:/ /ec.europa.eu/digitalagenda/en/news/pricing-public-sector-information-study-popsis-summary-report.

Deloitte LLP (2012). Open Growth: Stimulating demand for open data in the UK. A briefing note from Deloitte Analytics. London: Deloitte Touche Tohmatsu Limited. Retrieved November 27, 2013, from http://www2.deloitte.com/uk/en/pages/deloitte-analytics/articles/stimulating-demand-for-opendata-in-the-uk.html.

DotEcon (2015). Independent evaluation of the OFT's 2006 market study into the Commercial Use of Public Information (CUPI). A Report by DotEcon for the CMA. Retrieved March 26, 2015, from https://www.gov.uk/government/uploads/system/uploads/attachment_data/file/418097/Evaluati on_of_CUPI_study.pdf.

Ferro, E. and M. Osella (2013). Eight business model archetypes for PSI reuse. Open Data on the Web Workshop Shoreditch, London, 23rd-24th April 2013. Retrieved November 23, 2013, from http://www.w3.org/2013/04/odw/odw13_submission_27.pdf.

Fornefeld, M., G. Boele-Keimer, S. Recher and M. Fanning (2008). Assessment of the reuse of Public Sector Information (PSI) in the Geographic Information, Meteorological Information and Legal Information sectors - Final Report. Study commissioned by EC in 2007. Dusseldorf: MICUS, Retrieved December 2, 2008, from: http://ec.europa.eu/newsroom/document.cfm?doc_id=1258.

Granickas, K (2013). Understanding the impact of releasing and re-using open government data. European Public Sector Information Platform Topic Report No. 2013/08. Retrieved November 28, 2014, from http://epsiplatform.eu/sites/default/files/2013-08-Open_Data_Impact.pdf.

Grus, M. and D. te Winkel (2015). Assessment of the volunteered geographic information feedback system for the Dutch topographical key register. ISPRS Geospatial Week 2015, La Grande Motte, 28 Sep - 03 Oct 2015, doi:10.5194/isprsarchives-XL-3-W3-51-2015.

Houghton, J. (2011). Costs and benefits of data provision. Report to the Australian National Data Service. Melbourne: Centre for Strategic Economic Studies, Victoria University, Retrieved September 30, 2012, from http://ands.org.au/resource/houghton-cost-benefit-study.pdf. 
Huijboom, N. and T. van den Broek (2011). "Open Data: an international comparison of strategies." European Journal of ePractice no. 12 (March/April 2011):4-16. Retrieved April 14, 2015, from http:/ / sharepsi.eu/papers/TNO-epractice.pdf.

Janssen, M., Y. Charalabidis and A. Zuiderwijk (2012). Benefits, Adoption Barriers and Myths of Open Data and Open Government. Information Systems Management 29 (4):258-268. doi: $10.1080 / 10580530.2012 .716740$

Janssen, M. and A. Zuiderwijk (2014). Infomediary Business Models for Connecting Open Data Providers and Users. Social Science Computer Review 32 (5):563-576. doi: 10.1177/0894439314525902.

Jetzek, T (2013). The value of Open Government Data. Geoforum Perspectiv 12 (23 (2013)):47-56. Retrieved February 4, 2014, from http://journals.aau.dk/index.php/gfp/article/view/489/400.

Johnson, M.W., C.M. Christensen and H. Kagermann (2008). Reinventing your business model. Harvard Business Review. doi: https://hbr.org/2008/12/reinventing-your-business-model.

Kadaster (2012). Voor onbegrensde kansen. Jaarverslag 2011 [For unlimited chances. Annual report 2011], Apeldoorn. Retrieved June 30, 2014, from

http://www1.kadaster.nl/1/jaarverslag/2011/pdf/jaarverslag_2011.pdf.

Kadaster (2015). In beweging. Jaarverslag 2014 [On the move. Annual report 2014], Apeldoorn, Retrieved May 1, 2015, from http:/ /www.kadaster.nl/web/Jaarverslag-2014/2014-in-het-kort/Financieleresultaten.htm.

Kamer van Koophandel (2015). Transitie. Jaarverslag 2014 [Transition. Annual report 2014]. Retrieved July 31, 2015, from http://www.kvk.nl/download/KvK_jaarverslag_2014\%20_tcm109-406118.pdf.

Kelsey, J. and B. Schneider (1999). The street performer protocol and digital copyrights. First Monday 4 (6). doi: $10.5210 /$ fm.v4i6.673.

Koski, H. (2011). Does Marginal Cost Pricing of Public Sector Information Spur Firm Growth? Keskusteluaiheita Discussion Papers, 28 September 2011 no. 1260. Helsinki: ETLA - The Research Institute of the Finnish Economy, Retrieved November 28, 2011, from http://www.etla.fi/wpcontent/uploads/2012/09/dp1260.pdf.

Koski, H. (2015). The Impact of open data - a preliminary study. Helsinki: ETLA, Retrieved March 1, 2016, from https://www.w3.org/2013/sharepsi/wiki/images/6/67/Impact_of_Open_Data_in_the_Public_Sector_Koski_2015.pdf.

Krek, A. and A.U. Frank (2000). The Production of Geographic Information - The Value Tree. Journal for Spatial Information and Decision Making 13(3):10-12. Retrieved November 28, 2014, from https://www.researchgate.net/publication/2803544_The_Production_of_Geographic_Information__The_Value_Tree.

Longhorn, R.A. and M. Blakemore (2008). Geographic information: value, pricing, production, and consumption. Boca Raton: CRC Press, Taylor \& Francis Group.

Louzada, K. (2013). Crowdfunding, nu ook voor wetenschappers en academici. [Crowd funding, now also for scientists and academics]. Agentschap NL, Ministerie van Economische Zaken Retrieved September 17, 2014, from http://www.rvo.nl/sites/default/files/Crowdfunding\%20v2.pdf. 
Malone, T.W., P. Weill, R.K. Lai, V.T. D'Urso, G. Herman, T.G. Apel and S. Woerner (2006). Do Some Business Models Perform Better than Others? MIT Sloan working paper 4615-06, May 2006. doi: http://ssrn.com/paper=920667.

MRI [Market Rates Insight] (2012). First Integrated Study on Service Fees. Retrieved September 17, 2014, from http://www.marketratesinsight.com/news/NewsReleaseMRI_IntegratedStudy_FirstResults_052112.pdf.

Newbery, D., L. Bently and R. Pollock (2008). Models of Public Sector Information Provision via Trading Funds. Study commissioned jointly by the Department for Business, Enterprise and Regulatory Reform (BERR) and HM Treasury in July 2007. Cambridge: Cambridge University. Retrieved February 26, 2009, from

http://webarchive.nationalarchives.gov.uk/20090609003228/http://www.berr.gov.uk/files/file45136. pdf.

Omidyar Network (2014). Open for Business: How open data can help achieve the G20 growth target. A Lateral Economics report commissioned by Omidyar Network. Retrieved July 28, 2015, from https://www.omidyar.com/sites/default/files/file_archive/insights/ON\%20Report_061114_FNL.pdf

Onsrud, H.J. (1992). In support of cost recovery for publicly held geographic information. GIS Law 1(2):1-7. Retrieved August 1, 2008 from http://www.spatial.maine.edu/ onsrud/pubs/Cost_recovery_for_GIS.html.

Onsrud, H.J. (2004). The US national Spatial Data Infrastructure. Legal \& economic issues and developments. In B. van Loenen and B.C. Kok (eds), Spatial data infrastructure and policy development in Europe and the United States, pp. 87-100. Delft: OTB Research Centre for Housing, Urban and Mobility Studies.

Osterwalder, A. and Y. Pigneur (2010). Business Model Generation. Hoboken, NJ: John Wiley \& Sons.

Ovans, A. (2015). What is a business model? Harvard Business Review. Retrieved June 30, 2015, from https://hbr.org/2015/01/what-is-a-business-model\&cm_sp=Article-_-Links-_Top\%20of\%20Page\%20Recirculation\#.

PASC [Public Administration Select Committee] (2014). Public Administration Committee - Tenth Report. Statistics and Open Data: Harvesting unused knowledge, empowering citizens and improving public services. London. Retrieved March 17, 2015, from http://www.publications.parliament.uk/pa/cm201314/cmselect/cmpubadm/564/56402.htm.

Pira International Ltd, University of East Anglia and KnowledgeView Ltd. (2000). Commercial exploitation of Europe's public sector information - Final report. European Commission Directorate General for the Information Society. Retrieved September 20, 2006, from ftp://ftp.cordis.lu/pub/econtent/docs/commercial_final_report.pdf.

Rappa, M. (2010). Business models on the Web. (open educational resource). North Carolina State University Retrieved July 13, 2014, from. http://digitalenterprise.org/about.html.

RDW (2015). Jaarverslag 2014 [Annual report 2014]. Retrieved July 30, 2015, from http://jaarverslag.rdw.nl/Documents/Wettelijk\%20Jaarverslag\%202014.pdf. 
Reitsma, D. (2007). De consument en zijn behoefte aan geografische data. (The consumer and his requirements for geographical data). In Y. Pluijmers (ed), Werkconferentie RGI-117 Geodata, van verstrekking naar toegang, Den Haag, 13 February 2007. Bedrijvenplatform Geo-Informatie, Woerden, pp. 35-47.

Rhind, D. ed. (2014). What is the value of open data? What is the Value of Open Data? Proceedings of an APPSI Seminar on 28 January 2014, London, April 2014. Retrieved October 20, 2015, from https://www.nationalarchives.gov.uk/documents/meetings/20140128-appsi-what-is-the-value-ofopen-data.pdf.

Schiff, F. (2003). Business models of news web sites: a survey of empirical trends and expert opinions. First Monday [Online] 8, nr. 6 - June 2 2003:27. Retrieved May 13, 2008, from http://www.uic.edu/htbin/cgiwrap/bin/ojs/index.php/fm/article/view/1061/981.

Shapiro, C. and H.R. Varian (1999). Information Rules: a strategic guide to the network economy. 1 vols. Boston, Massachusetts: Harvard Business School Press.

Tennison, J. (2012). Open Data Business Models Jeni's Musings. Retrieved August 20, 2014, from http://www.jenitennison.com/blog/node/172.

TNO (2015). Annual Report 2014. Retrieved March 31, 2015, from https://www.tno.nl/media/5574/tno_annual_report_2014.pdf.

Twynstra Gudde, CE Delft and Tauw (2011). Maatschappelijke Kosten Baten Analyse van de Basisregistratie Ondergrond, fase 1 [Social cost-benefit analysis of the Key Register Subsurface, phase 1]. Amersfoort, Retrieved July 27, 2015 from: https://bro.pleio.nl/file/download/32139762.

Uhlir, P.F., ed. (2009). The socioeconomic effects of public sector information on digital networks. Towards a better understanding of different access and reuse policies - Workshop Summary. Washington:

National Academies Press. Retrieved March 1, 2010 from

http://www.nap.edu/openbook.php?record_id=12687.

van Loenen, B. (2006). Developing geographic information infrastructures: The role of information policies. PhD Dissertation, OTB Research Institute, Delft University of Technology.

van Loenen, B. (2009). Developing geographic information infrastructures: the role of access policies. International Journal of Geographical Information Science 23 (2) (2):195-212. doi: 10.1080/13658810701851412.

van Loenen, B. and M. Grothe (2014). INSPIRE Empowers Re-Use of Public Sector Information. International Journal of Spatial Data Infrastructures Research 9 (2014):86-106. doi: 10.2902/1725-0463.2014.09.art4.

van Loenen, B. and J. Zevenbergen (2010). Assessing geographic information enhancement. International Journal of Spatial Data Infrastructures Research 5 (2010):244-266. doi: 10.2902/1725-0463.2010.05.art10.

van Loenen, B., J. Zevenbergen and J. de Jong. 2006. Access to government information unnecessary remains a case of professional elite. Shaping the Change, XXIII FIG Congress Munich, Germany, 8-13 October 2006.

Verdonck Klooster \& Associates, Ecorys and Berenschot (2014). Businesscase SGO-3. Maatregel 4: Open data [Business case SGO-3. Measure 4: Open data]. Retrieved May 22, 2014, from 
http://www.rijksoverheid.nl/documenten-en-publicaties/publicaties/2014/05/22/business-cases5.html.

Vickery, G. (2011). Review of recent studies on PSI reuse and related market developments. Paris: Information Economics. Retrieved November 1, 2011, from http://ec.europa.eu/digitalagenda/en/news/review-recent-studies-psi-reuse-and-related-market-developments.

Wang, C.L., Y. Zhang, L.R. Ye and D.-D. Nguyen (2005). Subscription to fee-based online services: what makes consumer pay for online content? Journal of Electronic Commerce Research 6 (4):304-311. Retrieved June 30, 2015 from http:// www.isy.vcu.edu/ jsutherl/Info658/FFSINFO.pdf.

Welle Donker, F. (2009). Public sector geo web services: which business model will pay for a free lunch? In B. van Loenen, J.W.J. Besemer and J.A. Zevenbergen (eds), SDI Convergence: Research, Emerging Trends, and Critical Assessment, pp. 35-51. Delft: Nederlandse Commissie voor Geodesie / Netherlands Geodetic Commission (NCG).

Welle Donker, F., B. van Loenen and A.K. Bregt (2016). Open Data and Beyond. ISPRS International Journal of Geo-Information 5 (4). doi: 10.3390/ijgi5040048.

Zhang, B., L. Collins and P. Baeck (2014). Understanding alternative finance. The UK Alternative Finance Industry Report 2014. London: Nesta, Retrieved November 30, 2015, from https://www.jbs.cam.ac.uk/fileadmin/user_upload/research/centres/alternativefinance/downloads/2014-uk-alternative-finance-benchmarking-report.pdf.

\section{About the Authors}

\section{Frederika Welle Donker}

Frederika Welle Donker is a researcher attached to the Knowledge Centre for Geo-information Governance, part of the Geo-information Technology and Governance Research Programme of the Faculty of Architecture and the Built Environment, Delft University of Technology. Her research focuses on the legal, economic and institutional aspects of open data and on the stimulation of reuse of public sector information. She will defend her thesis at the end of 2016.

\section{Bastiaan van Loenen}

Bastiaan van Loenen is Associate Professor attached to the Knowledge Centre for Geoinformation Governance and is chairing the Geo-information studies theme group at the OTB Research Institute for the Built Environment. His research focuses on the stimulation of open data reuse and on the legal aspects of geographic information (e.g. privacy, harmonising licences, intellectual property rights). 